\title{
Emilia Wq̨ikiewicz-Firlej
}

Uniwersytet im. Adama Mickiewicza w Poznaniu emiliawf@amu.edu.pl

\section{Hadrian Lankiewicz}

Uniwersytet Gdański

hadrian.lankiewicz@ug.edu.pl

\section{WYKORZYSTANIE NARRACJI BIOGRAFICZNYCH W REFLEKSJI NAD KSZTAŁCENIEM NAUCZYCIELI JĘZYKÓW OBCYCH}

\section{The use of narrative biographies in reflection on the education of foreign language teachers}

This paper attempts to contribute to the discussion on the use of biographical narratives in investigating FL teacher careers and bring to light their potential in teacher education, especially in the process of developing teacher identity and reflexivity. Biographical narratives provide in-depth insights into individual professional careers which are viewed holistically, in the context the narrator's life. Focused on the subjective dimensions of professional careers, narratives involve identification and interpretation of key events and persons in particular life stories, which stimulate the narrator's reflexivity and enable them to find connections between episodes and make them meaningful.

Keywords: narrative research, biographical narratives, reflexivity, FL teacher careers, FL teacher education

Słowa kluczowe: badania narracyjne, narracje biograficzne, refleksyjność, kariera nauczycieli języków obcych, kształcenie nauczycieli języków obcych

\section{Wprowadzenie}

Kwestie związane z przygotowaniem absolwentów do realnych wymogów rynku pracy, podjęciem zatrudnienia oraz przebiegiem ich kariery zawodowej 
stały się kluczowymi wyzwaniami dla wyższych uczelni. W wyniku licznych zmian o charakterze ekonomicznym, społecznym i politycznym na przestrzeni ostatnich 20 lat znacząco zmienił się przebieg oraz charakter kariery zawodowej, która - wcześniej postrzegana jako linearna, uporządkowana i przewidywalna (Gutteridge, 1986) - stała się płynna, wielokierunkowa i trudna do przewidzenia (Arthur i Rousseau, 1996; Lichtenstein i Mendenhall, 2002). Zmiany te nie ominęły również sektora edukacji, a tym samym wywarły wpływ na rozwój zawodowy nauczycieli oraz sposób badania ich kariery zawodowej. Związany jest z tym dynamiczny rozwój badań narracyjnych, w szczególności tych o charakterze biograficznym, zapoczątkowany $w$ latach dziewięćdziesiątych ubiegłego wieku (Connelly i Clandini, 1990). W tym kontekście celem artykułu jest podjęcie dyskusji poświęconej wykorzystaniu narracji biograficznych w badaniu karier zawodowych nauczycieli języków obcych. Narracja biograficzna jako podejście badawcze o charakterze jakościowym umożliwia holistyczne ujęcie problemu kariery zawodowej oraz uchwycenie jej subiektywnego wymiaru, obejmującego interpretację poszczególnych wydarzeń, punktów zwrotnych i kluczowych postaci w życiu badanych oraz ewaluację ich znaczenia. Potencjał badań narracyjnych w kształceniu nauczycieli języków obcych, a w szczególności kształtowaniu ich tożsamości zawodowej oraz refleksyjności, zostanie pokazany na przykładzie analizy dwóch wybranych narracji biograficznych nauczycieli języka angielskiego, rozumianych jako „studium przypadku kariery” (Hughes, 1997: 390).

\section{Pojęcie kariery zawodowej}

W tradycyjnym ujęciu kariera zawodowa była postrzegana w sposób linearny, miała jednostajny przebieg, zwykle w jednym sektorze gospodarki czy wręcz przedsiębiorstwie lub instytucji (Hall, 1976; Schein, 1978; za: Grabowska-Lusińska i Jaźwińska-Motylska, 2013: 13). W badaniach socjologicznych, głównie o charakterze ilościowym, kariera postrzegana była jako uporządkowane zajmowanie pozycji zawodowych według określonej hierarchii i w określonym czasie oraz aktywność zawodowa jednostek na poszczególnych etapach życia (Pohoski, 1984; Mach, 2003; 2005 za: Grabowska-Lusińska i Jaźwińska-Motylska, 2013: 13). Z tego względu kariera była racjonalnie planowana i stosunkowo przewidywalna (Gutteridge, 1986).

Jednakże wskutek głębokich zmian o charakterze ekonomicznym, politycznym i technologicznym na niespotykaną dotąd skalę, które miały miejsce na przestrzeni kilku ostatnich dekad, model kariery polegający na rozwijaniu kompetencji zawodowych w ramach jednej organizacji z korzyścią dla niej uległ w znacznej mierze dezaktualizacji. Miejsce pracy stało się mniej stabilne, co wywołało z kolei potrzebę kształcenia się przez całe życie i rozwijania umiejętności 
miękkich, np. komunikacji i negocjacji (Blocher i in., 2001). Badacze zwrócili również uwagę na „wielopłaszczyznowość, wielowątkowość i dynamikę przebiegu karier zawodowych" (Grabowska-Lusińska i Jaźwińska-Motylska, 2013: 14), które stały się płynne (ang. boundaryless), wielowymiarowe i trudne do przewidzenia (Arthur i Rousseau, 1996) oraz kształtowane przez szereg czynników (Lichtenstein i Mendenhall, 2002). Takie ujęcie umożliwia uchwycenie dynamiki i specyfiki współczesnego rynku pracy oraz zrozumienie mechanizmów, które go kształtują w nieustannie przeobrażających się realiach społecznych (Matusik i Hill, 1998).

Zmiany w sposobie funkcjonowania w miejscu pracy w nowej, wolnorynkowej rzeczywistości, w warunkach ostrej konkurencji, przyczyniły się do powstania nowego modelu kariery typu patchwork, który również jest widoczny w przebiegu pracy zawodowej nauczycieli. Kariera tego typu jest warunkowana zewnętrznie przez określoną rzeczywistość społeczno-ekonomiczną, w związku z czym kształtowana jest przypadkowo, często nieświadomie i chaotycznie (Kędzierska, 2011: 84).

Patchwork wiąże się z wymuszonymi przez czynniki zewnętrzne zmianami miejsc pracy bądź też równoległym wykonywaniem zróżnicowanych czynności zawodowych, niemających ze sobą wiele wspólnego zarówno w sensie wymaganych kompetencji, jak i branży, w której się pracuje (Domecka i Mrozowicki, 2008: 114).

Skutkiem tych zmian, jak również niżu demograficznego, jest destabilizacja zatrudnienia i zaburzony rozwój kariery zawodowej nauczycieli, w wielu wypadkach zmuszonych do podjęcia zatrudnienia w kilku placówkach jednocześnie - często na niekorzystnych zasadach finansowych - i dostosowania się do zmieniających się wymogów rynku pracy (por. Kędzierska, 2011).

Kariery nauczycielskie, tak jak i kariery w przemyśle i biznesie, «zaczynają przypominać serie gościnnych występów na deskach kolejnych organizacji i projektowych teatrów [...], w których nie ma gwarancji na happy end» [Magala, 2005: 207], choć w zawodzie nauczycielskim dokładnie nie wiadomo, co mogłoby zostać uznane za szczęśliwy koniec (Kędzierska, 2011: 86).

Samo pojęcie kariery zawodowej ma zarówno wymiar obiektywny, jak i subiektywny. Aspekt obiektywny odnosi się do zmiany poziomu uczestnictwa w organizacji, dla której dana jednostka świadczy pracę, uzewnętrzniany w postaci przesunięć wertykalnych - w górę jako awans zawodowy lub w dół jako degradacja - ewentualnie horyzontalnych jako zmiana zawodu o podobnym charakterze, bez istotnych różnic w jego prestiżu lub wynagrodzeniu (Kędzierska, 2011; Domecka i Mrozowicki, 2008). Wymiar subiektywny obejmuje z kolei 
kształtowanie się tożsamości i zmianę na poziomie jednostkowym oraz w kontekście otaczającego środowiska, jak również refleksję nad przebiegiem całego życia i interpretację znaczenia poszczególnych jego elementów, tj. wydarzenia, działania, sprawy, w które zaangażowana jest dana jednostka (Domecka i Mrozowicki, 2008; Domecka, 2010). Zaznaczyć należy, iż praca stanowi jedno z najważniejszych źródeł identyfikacji i ma kluczowe znaczenie dla procesu kształtowania tożsamości zarówno zawodowej, jak i personalnej (Kędzierska, 2011: 80).

Te dwa wymiary kariery znajdują również odzwierciedlenie w jakościowych podejściach metodologicznych zaproponowanych w opracowaniu BorniańskoSulinowskiej i Jaźwińskiej-Motylskiej (2013: 15), tj. wywiadu ustrukturyzowanego i narracji biograficznych, które zostaną omówione w następnej sekcji.

\section{Badanie kariery zawodowej: w stronę narracji biograficznych}

Wywiad ustrukturyzowany jako narzędzie badawcze umożliwia zapoznanie się z przebiegiem kariery zawodowej głównie pod kątem charakteru czasu trwania zatrudnienia $w$ danym miejscu pracy i sekwencji zajmowanych stanowisk. Mimo iż narzędzie to pozwala na zachowanie obiektywizmu, ma jednak pewne istotne ograniczenia. Przede wszystkim nie uwzględnia kontekstu społecznego danej kariery ani refleksji respondenta na temat znaczenia poszczególnych prac, wydarzeń czy też punktów zwrotnych w przebiegu własnej kariery zawodowej (Grabowska-Lusińska i Jaźwińska-Motylska, 2013).

Narracje biograficzne z kolei koncentrują się na subiektywnych aspektach kariery zawodowej, ze szczególnym naciskiem na tworzenie się tożsamości zawodowej jednostki. Nie stoją one jednak w opozycji do wywiadów ustrukturyzowanych, lecz stanowią ich uzupełnienie o elementy wymienione powyżej i pozwalają na:

1. uchwycenie mobilności w ramach tej samej kategorii zawodowej,

2. zbadanie refleksyjności respondenta (lub jej braku) w odniesieniu do całości przebiegu kariery zawodowej oraz w nadawaniu znaczeń kolejnym jej etapom i poszukiwaniu punktów zwrotnych i splotów wydarzeń,

3. uchwycenie sekwencji kolejnych prac w specyficznym kontekście społecznostrukturalnym (Grabowska-Lusińska i Jaźwińska-Motylska, 2013: 16).

Hughes (1997) stoi na stanowisku, iż kariera nie może być rozpatrywana w oderwaniu od całości życia danej jednostki, ponieważ jest jego integralną częścią, konstruowaną przez wszystkie jego elementy, nie tylko te profesjonalne. $Z$ tego względu pojedynczą biografię należy rozpatrywać jako "studium przypadku kariery" (Hughes, 1997: 390; za: Domecka i Mrozowicki, 2008: 3), 
sprzyjające wieloaspektowemu badaniu karier zawodowych. Narracje biograficzne umożliwiają identyfikację roli poszczególnych wydarzeń i osób, określenie punktów zwrotnych karier (por. Strauss, 1977: 93), jak również odzwierciedlają zmiany na poziomie społeczno-strukturalnym (Bertaux i Kohli, 1984: 219) oraz tożsamości jednostek (Schütze, 2005).

Zwrot w kierunku podejścia narracyjnego do badania kariery zawodowej wydaje się wysoce zasadny w kontekście współczesnego zglobalizowanego świata, borykającego się z licznymi problemami natury politycznej i ekonomicznej, oraz ma istotną przewagę nad tradycyjnie stosowanymi w tego typu badaniach narzędziami psychometrycznymi. Przede wszystkim stawia osobę badaną w pozycji narratora, który przyjmuje aktywną rolę i przez werbalizację swych doświadczeń nadaje im znaczenie oraz uczy się, jak dzielić swoje narracje z innymi (Reid, 2005; 2006, w: Wąsikiewicz-Firlej, 2013: 181). Inną istotną zaletą podejścia narracyjnego jest jego wymiar interkulturowy, umożliwiający badaczowi spojrzenie na doświadczenie zawodowe pod kątem różnic na poziomie indywidualnym i kulturowym, jak również czynników środowiskowych i kontekstowych, które mogą ulec zmianie w czasie (Reid, 2003). Poza tym narracje mają wysoki potencjał edukacyjny, ponieważ poprzez retrospektywne spojrzenie na własne doświadczenia pomagają w ich uporządkowaniu i nadaniu im znaczenia. Co więcej, są pomocne w długoterminowym planowaniu kariery oraz pozwalają na rzetelną ocenę własnych słabych i mocnych stron (por. Stebleton, 2010: 68-69). Podejście to ma jednak pewne ograniczenia. Przede wszystkim jest niezwykle czasochłonne i wymaga dużego zaangażowania ze strony respondenta-narratora oraz badacza, który musi zmierzyć się z analizą ogromnej ilości danych wygenerowanych podczas badania (Hardy, 2001; Reid, 2006). Mimo tych trudności podejście narracyjne może być z powodzeniem stosowane jako zasadnicza metoda badania karier nauczycielskich (np. Michalak, 2007; Nizińska, 2008; Werbińska, 2009).

\section{Opis badania}

Niniejsze badanie jest częścią projektu realizowanego na przełomie roku 2012/2013, który objął 11 narracji nauczycieli języka angielskiego (wyniki zostały opublikowane w: Wąsikiewicz-Firlej, 2013, 2014). Celem przeprowadzonej analizy jest określenie modelu przebiegu kariery zawodowej w odniesieniu do uwarunkowań wewnętrznych i zewnętrznych oraz dynamiki procesu kształtowania się tożsamości nauczycieli. Rozważaniom poddana zostanie również możliwość wykorzystania narracji biograficznych w kształceniu nauczycieli oraz kształtowaniu ich refleksyjności. Przedmiotem analizy są dwie narracje biograficzne - traktowane jako studium przypadku kariery - nauczycielek języka 
angielskiego o podobnym doświadczeniu zawodowym (14 lat) i wykształceniu (uniwersyteckie studia magisterskie realizowane $w$ trybie stacjonarnym). Obydwie respondentki są obecnie zatrudnione w pełnym wymiarze godzin w społecznej szkole podstawowej i średniej, w mieście pow. 100 tys. mieszkańców. Dane do analizy narracyjnej zostały uzyskane na podstawie wywiadu pogłębionego oraz pisemnych refleksji respondentek dostarczonych po zakończeniu badania. Każdy z wywiadów trwał ok. 45 minut i został nagrany, a następnie poddany transkrypcji verbatim przy zastosowaniu uproszczonych konwencji (Boje, 1991).

Metodologia analizy danych została opracowana na podstawie analizy narracyjnej przeprowadzonej przez Ruohotie-Lythy (2013) i obejmowała kolejno takie etapy, jak:

- wielokrotne czytanie narracji, identyfikacja wydarzeń (por. Labov i Waletzky, 1967/2008);

- identyfikacja motywów przewodnich i łączenie ich w kategorie (PoIkingthorne, 1996);

- narracyjna interpretacja danych (Polkingthorne, 1996), zakładająca „rekonstrukcję narracji przez badacza poprzez znalezienie sposobu, aby zrozumieć rozwój wątków" (Squire, 2008; tłum. własne).

\subsection{Analiza biografii}

W celu zachowania anonimowości autorkom analizowanych narracji zostały nadane fikcyjne imiona: Anastazja i Ewa. Poniżej przedstawione zostały ich profile biograficzne.

\section{Anastazja}

Anastazja pochodzi z rodziny nauczycielskiej. Jej matka pracowała jako nauczycielka z dziećmi niepełnosprawnymi i wykazywała się dużym zaangażowaniem w swoją pracę zawodową, co wzbudzało podziw i uznanie jej córki. Szacunek, którym darzyła matkę, przeniesiony został automatycznie na całą grupę zawodową nauczycieli. Fakt ten wywarł istotny wpływ na pozytywne postrzeganie profesji nauczycielskiej przez respondentkę na późniejszym etapie jej życia, jak również na wybór zawodu oraz proces kształtowania się jej tożsamości nauczyciela: „Wybór zawodu to nie był przypadek. Pracuję w szkole, bo uważam, że się do tego nadaję".

Z obiektywnego punktu widzenia przebieg kariery zawodowej respondentki jest wręcz modelowy. Poza krótkim, nieudanym epizodem wykonywania pracy o charakterze biurowym jej kariera zawodowa związana była z sektorem edukacji. Negatywne doświadczenie z pracy w biurze, które określiła jako 
„więzienie”, pozbawione stymulujących ją bodźców, takich jakich różnorodność podejmowanych zadań i kontaktów międzyludzkich, utwierdziło ją w słuszności swoich dalszych decyzji dotyczących wyboru ścieżki kariery. Pracę w szkolnictwie podjęła zaraz po ukończeniu studiów magisterskich w 1999 r. i od tego momentu nieprzerwanie pracuje w zawodzie nauczyciela. Co więcej, jest to jej druga praca w szkolnictwie. Pierwsze zatrudnienie podjęła w dużej osiedlowej szkole w mieście wojewódzkim pow. 100. tys. mieszkańców, lecz po roku zaczęła pracę w renomowanej szkole społecznej, z którą jest związana do dziś. Powodem jej decyzji było niesatysfakcjonujące wynagrodzenie. Nowe miejsce pracy w pełni spełniło jej oczekiwania, zarówno finansowe, jak i te związane z rozwojem osobistym - szkoła stwarza możliwości rozwoju zawodowego i personalnego poprzez możliwość uczestnictwa w szeregu szkoleń i projektów edukacyjnych. Formalnie respondentka uzyskała najwyższy stopień awansu zawodowego w karierze nauczyciela i pełni funkcję lidera zespołu nauczycieli języków obcych. Na obecnym etapie nie jest zainteresowana dalszym awansem w strukturze pionowej placówki, chce jednak pogłębiać swoje kompetencje pedagogiczne. Respondentka silnie identyfikuje się ze swoim miejscem pracy i nie rozważa jego zmiany, mimo iż obecne wynagrodzenie uważa za zbyt niskie i zmuszona jest podejmować dodatkową pracę, udzielając prywatnych lekcji oraz prowadząc kursy językowe. W ostatnim czasie zauważyła jednak pewną zmianę w relacjach koleżeńskich wywołaną - jej zdaniem - czynnikami zewnętrznymi, takimi jak niż demograficzny i nasycenie rynku pracy anglistami.

Jeszcze parę lat temu więcej czasu spędzaliśmy ze sobą... wychodziliśmy na miasto, organizowaliśmy wspólne imprezy... teraz tego już nie ma, nie na taką skalę... może to kwestia wieku... nie wiem... a może bardziej patrzymy na siebie jak na konkurencję...

Respondentka uświadomiła sobie również, jak bardzo zmieniło się jej podejście do sprawowania funkcji wychowawcy. Z osoby początkowo niekompetentnej i nieprzygotowanej, niechętnie odgrywającej tę rolę, stała się w pełni zaangażowanym wychowawcą, odpowiedzialnym za uczniów.

\section{Ewa}

W przeciwieństwie do Anastazji Ewa nigdy nie planowała kariery nauczycielskiej, która w jej rodzinie nie była postrzegana pozytywnie. Pomimo negatywnej motywacji do tej profesji, respondentka zaczęła pracować w charakterze nauczyciela języka angielskiego ze względów pragmatycznych: w późnych latach 90. praca ta była stosunkowo łatwo dostępna i dobrze płatna. Pomimo tego, na początku kariery towarzyszyło jej poczucie frustracji i rozczarowania, pogłębiane 
dodatkowo przez postawę rodziców, którzy nie do końca akceptowali jej życiowe wybory. Praca ta była przez nią postrzegana wyłącznie w kategoriach zarobkowych i traktowana jako tymczasowa - do momentu znalezienia „prawdziwej" pracy w korporacji. Respondentka nie była związana z placówką szkolną, lecz prowadziła działalność gospodarczą, współpracując głównie ze szkołami językowymi oferującymi kursy językowe dla firm. Dodatkowo zajmowała się również tłumaczeniami. Na tym etapie jej kariera miała charakter „patchworkowy" - nie była związana z jedną konkretną instytucją i wykluczała zdobywanie kolejnych stopni awansu zawodowego na formalnej ścieżce kariery w szkolnictwie, a polegała raczej na świadczeniu zróżnicowanych usług językowych wielu podmiotom gospodarczym. Z biegiem czasu początkowa, silnie zakorzeniona niechęć do profesji nauczycielskiej ustąpiła akceptacji i poczuciu satysfakcji z wykonywanej pracy, w dużej mierze ze względu na pozytywną ocenę jej pracy przez zleceniodawców i kursantów. Momentem zwrotnym w jej biografii było macierzyństwo, które diametralnie zmieniło jej ścieżkę kariery.

Ze względu na komplikacje $w$ trzecim miesiącu ciąży musiałam przerwać pracę... z dnia na dzień zostałam praktycznie bez dochodu... miałam jakieś grosze z ZUS dla prowadzących działalność... to był chyba najgorszy okres mojego życia... strasznie się denerwowałam...*** Gdy dziecko miało dwa miesiące nocami zamiast spać ślęczałam nad tłumaczeniami, żeby jakoś załatać budżet.

Po tym doświadczeniu respondentka podjęła zatrudnienie jako anglistka w społecznej szkole podstawowej i gimnazjum. W ciągu niespełna 10 lat płynnie przeszła wszystkie stopnie awansu zawodowego i osiągnęła status nauczyciela dyplomowanego. Obecnie silnie identyfikuje się ze swoją profesją i miejscem pracy, jak również deklaruje chęć rozwoju swoich kompetencji pedagogicznych. Pewien niepokój wzbudza w niej jednak fakt, że obecnie praca wydaje się jej nieco mniej stabilna ze względu na niż demograficzny oraz obawy związane z rekrutacją i zapewnieniem pensum dydaktycznego. Znajduje to - jej zdaniem - odzwierciedlenie w relacjach koleżeńskich, które stały się bardziej napięte i charakteryzują się nieco większym współzawodnictwem niż w przeszłości:

Mam wrażenie, że kiedyś byliśmy bardziej zżyci. Byliśmy my i dyrekcja. Teraz widzę, że każdy stara się wykazać, coś organizować... niektórzy starają się wydeptać ścieżkę do gabinetu pani dyrektor....

Motywy przewodnie narracji respondentek na poszczególnych etapach kariery zostały zestawione $w$ tabeli 1 . poniżej. 
Wykorzystanie narracji biograficznych w refleksji nad kształceniem nauczycieli...

\begin{tabular}{|c|c|c|}
\hline $\begin{array}{l}\text { Motywy przewodnie } \\
\text { narracji }\end{array}$ & Anastazja & Ewa \\
\hline $\begin{array}{l}\text { Motywy przewodnie nar- } \\
\text { racji przed rozpoczęciem } \\
\text { kariery }\end{array}$ & $\begin{array}{l}\text { - planowanie } \\
\text { - określanie priorytetów }\end{array}$ & $\begin{array}{l}\text { - dążenie do osiągnięcia sukcesu za- } \\
\text { wodowego poza szkolnictwem } \\
\text { - silna presja zewnętrzna }\end{array}$ \\
\hline $\begin{array}{l}\text { Motywy przewodnie nar- } \\
\text { racji na początku kariery }\end{array}$ & $\begin{array}{l}\text { - uczenie się } \\
\text { - zdobywanie kompetencji peda- } \\
\text { gogicznych } \\
\text { - relacje z otoczeniem } \\
\text { - współpraca }\end{array}$ & $\begin{array}{l}\text { - rozczarowanie } \\
\text { - frustracja } \\
\text { - poszukiwanie alternatywnych } \\
\text { ścieżek kariery } \\
\text { - brak identyfikacji z zawodem } \\
\text { nauczyciela }\end{array}$ \\
\hline $\begin{array}{l}\text { Motywy przewodnie nar- } \\
\text { racji na dalszym etapie } \\
\text { kariery (po } 5 \text { latach) }\end{array}$ & $\begin{array}{l}\text { - rozwój zawodowy } \\
\text { - satysfakcja zawodowa } \\
\text { - wyzwania } \\
\text { - współpraca }\end{array}$ & $\begin{array}{l}\text { - brak stabilizacji finansowej } \\
\text { - obciążenie pracą } \\
\text { - brak poczucia rozwoju } \\
\text { zawodowego } \\
\text { - brak utożsamienia się z pracą } \\
\text { - macierzyństwo }\end{array}$ \\
\hline $\begin{array}{l}\text { Motywy przewodnie nar- } \\
\text { racji na obecnym etapie } \\
\text { kariery }\end{array}$ & $\begin{array}{l}\text { - satysfakcja zawodowa } \\
\text { - szacunek } \\
\text { - ja jako pedagog } \\
\text { - konkurencyjność } \\
\text { - pogarszające się relacje } \\
\text { koleżeńskie }\end{array}$ & $\begin{array}{l}\text { - stopniowa identyfikacja zawodowa } \\
\text { - satysfakcja zawodowa } \\
\text { - szacunek } \\
\text { - ja jako pedagog } \\
\text { - konkurencyjność } \\
\text { - pogarszające się relacje } \\
\text { koleżeńskie }\end{array}$ \\
\hline
\end{tabular}

Tabela 1: Motywy przewodnie narracji.

Analizowane biografie wyraźnie pokazują znaczenie nastawienia do zawodu oraz zmienność i dynamikę procesu kształtowania się tożsamości zawodowej. Warto również zwrócić uwagę na przeplatanie się motywów perturbacji osobistych i zawodowych oraz ich wzajemny wpływ. Narracja biograficzna umożliwiła respondentkom konsolidację rozmaitych doświadczeń zebranych na przestrzeni całego życia i zrozumienie ich sensu w danym jego momencie (por. Błaszak, 2011: 140), co zostało odzwierciedlone w pisemnych refleksjach dotyczących sesji narracyjnej nadesłanych przez respondentki po zakończeniu badania.

\subsection{Refleksje respondentek}

Obydwie respondentki przyznały, że sesja narracyjna pozwoliła im całościowo spojrzeć na ścieżkę swojej kariery zawodowej. Anastazja przyznała, że rzadko rozważała jej przebieg z perspektywy retrospektywnej; koncentrowała się raczej na kwestiach związanych z przyszłością, czyli jej planowaniem i perspektywach.

Rzadko rozmyślałam nad przebiegiem swojej kariery jako całości, koncentrowałam się raczej na poszczególnych problemach, które starałam się rozwiązać 
[...]. Na pewno nie mówiłam o tym na głos. [...]. W ten sposób rzeczywiście można sobie wszystko uporządkować i zrozumieć, jak poszczególne elementy wpływają na całość.

Respondentka uświadomiła sobie również, jak na poszczególnych etapach życia zmieniała się jej tożsamość zawodowa. Choć wybór jej profesji nie był przypadkowy, początkowo pozycjonowała siebie głównie jako nauczyciela języka angielskiego, przykładając mniejszą wagę do pedagogiczno-wychowawczych aspektów jej pracy, co zmieniło się w ciągu ostatnich lat.

Podobnie ewoluowała tożsamość zawodowa drugiej respondentki, która z „pragmatycznej karierowiczki” stała się świadomym nauczycielem-pedagogiem, w pełni akceptującym swoją rolę zawodową i mającym poczucie pewnej misji:

[...] zrozumiałam jak wiele czasu straciłam, miotając się po studiach i snując nierealne wizje kariery [...] moje oczekiwania były zupełnie nieadekwatne do rzeczywistości [...]. Zdałam też sobie sprawę, jak bardzo wpłynęły na mnie opinie innych osób, szczególnie rodziców, których wymaganiom nie potrafiłam sprostać [...]. Na początku chodziło mi tylko o zarabianie pieniędzy i własny rozwój. Teraz naprawdę zależy mi na tych dzieciakach. Chcę im pomóc, nie tylko w kwestiach związanych z nauką języka. Chcę, żeby znajdowali radość w uczeniu się i podejmowali właściwe decyzje życiowe.

Jak przyznały obydwie respondentki, sesja narracyjna zainspirowała je do dalszych rozważań i wymiany doświadczeń zawodowych z innymi nauczycielami w ich miejscu pracy. Podkreślona została szczególnie rola werbalizacji swoich narracji i dzielenia się z innymi (dalsza dyskusja w: Lankiewicz, 2014; Wąsikiewicz-Firlej, 2014).

\section{Wnioski}

Narracje biograficzne odgrywają istotną rolę w kształtowani tożsamości zawodowej, umożliwiając określenie swojej funkcji społecznej, momentu kariery i jej dalszych kierunków, autopostrzegania oraz postrzegania przez otoczenie, a także ułatwiają identyfikację punktów zwrotnych i kluczowych postaci. Odwołując się do słów Błaszaka (2011: 128): „Nasza tożsamość rodzi się przez nadanie wewnętrznej spójności własnej historii życia, w której każdy epizod może być odniesiony do całości, do głównego, indywidualnego wątku narracyjnego".

Poprzez nadawanie znaczenia poszczególnym epizodom i poszukiwanie wzajemnych powiązań pomiędzy różnorodnymi aspektami życia własna narracja stymuluje refleksyjność. Ponadto porównanie doświadczeń oraz formułowanie i uzasadnianie swojego stanowiska pozwala odkrywać i modyfikować 
teorie osobiste nauczycieli, czyli budować wiedzę w działaniu. Istotne wydaje się też uświadomienie sobie znaczenia samego pojęcia kariery rozumianej holistycznie i jej powiązań ze wszystkimi aspektami życia.

W wymiarze praktycznym należy podkreślić znaczenie narracji w monitorowaniu karier absolwentów. W przeciwieństwie do badań ilościowych, skupiających się na obiektywnym wymiarze kariery, przeprowadzanych często przez uczelniane biura karier, narracje pozwalają określić jej subiektywny, indywidualny wymiar - bardziej adekwatny dla kandydatów na nauczycieli. Mimo iż badania tego typu są trudne do przeprowadzenia na szeroką skalę ze względu na pracochłonność, indywidualne narracje odzwierciedlają zachodzące zmiany społeczne, przez co pozwalają na określenie rzeczywistych problemów, a w rezultacie bardziej świadome planowanie kariery. Z tego względu narracje biograficzne stanowią istotną wartość dla adeptów profesji nauczycielskiej i powinny się stać integralnym elementem kształcenia nauczycieli. Obecnie duży nacisk kładzie się na kwestię przygotowania do zawodu - za mało jednak mówi się o samym procesie kształtowania tożsamości zawodowej, jego dynamice czy problemach na poszczególnych etapach kariery. Studenci czują się bardzo dobrze przygotowani do pracy w szkole pod względem językowym i metodycznym, lecz zupełnie nieprzygotowani na rzeczywistość instytucjonalną polskich placówek oświatowych, co może się przełożyć na szybkie wypalenie zawodowe (Wąsikiewicz-Firlej, 2013). Postulat wprowadzenia zagadnień związanych z tożsamością nauczyciela w celu ułatwienia adaptacji początkujących nauczycieli pojawił się w szeregu prac (np. RuohotieLythy, 2013; Beauchamp i Thomas, 2009, 2011). Biografie doświadczonych nauczycieli mogą być zatem traktowane jako wartościowe materiały dydaktyczne, wprowadzające młodych adeptów nauczania w arkana ich profesji przy jednoczesnej minimalizacji ewentualnego ryzyka niepowodzenia.

\section{BIBLIOGRAFIA}

Arthur, M. B., Rousseau, D. M. 1996. The Boundaryless Career: New Employment Principle for a New Organisational Era. New York: Oxford University Press.

Beauchamp, C., Thomas, L. 2009. „Understanding teacher identity: An overview of issues in the literature and implications for teacher education". Cambridge Journal of Education 39(2): 175-189.

Beauchamp, C., Thomas, L. 2011. "New teachers' identity shifts at the boundary of teacher education and initial practice". International Journal of Educational Research 50(1): 6-13.

Bertaux, D., Kohli, M. 1984. „The life story approach. A continental view”. Annual Review of Sociology 10: 215-237.

Błaszak, B. 2011. „Tożsamość człowieka a pojęcie narracji”. Analiza i Egzystencja 14: 123-140. 
Blocher, D., Heppner, M. J., Johnstone, J. 2001. „The world of work: New paradigms mean new challenges". Counselling and Human Development 33: 1-8.

Boje, D. M. 1991. „The storytelling organization: A study of story performance in an office-supply firm". Administrative Science Quarterly 36(1): 106-126.

Connelly, F. M., Clandini, D. J. 1990. „Stories of experience and narrative inquiry”. Educational Researcher 19(5): 2-14.

Domecka, M. 2010. „Konstrukcja kariery, konstrukcja biografii, konstrukcja siebie. Narracje autobiograficzne ludzi biznesu" (w) Procesy tożsamościowe. Symbolicznointerakcyjny wymiar konstruowania ładu i nieładu społecznego (red. K. T. Konecki, A. Kacperczyk). Łodź: Wydawnictwo Uniwersytetu Łódzkiego: 200-201.

Domecka, M., Mrozowicki, A. 2008. „Robotnicy i ludzie biznesu. Wzory karier zawodowych a zmiana społeczna w Polsce”. Przegląd Socjologii Jakościowej 4(1): 136-155. http://przegladsocjologiijakosciowej.org/Volume6/PSJ_4_1_Domecka_Mrozo wicki.pdf DW30.06.2014.

Gutteridge, T. 1986. „Organizational career development systems: The state of the practice" (w) Career Development in Organizations (red. D. T. Hall). San Francisco, CA: Jossey-Bass: 50-94.

Hall, D. T. 1976. Careers in Organizations. Santa Monica: Goodyear Publishing Company.

Hardy, C. 2001. „Researching organisational discourse”. International Studies of Management and Organisation 31(3): 25-47.

Hughes, E. 1997. „Careers”. Qualitative Sociology 20(3): 389-397.

Grabowska-Lusińska, I., Jaźwińska-Motylska, E. 2013. „Problemy koncepcyjno-metodologiczne w badaniu mobilności społecznej i karier zawodowych migrantów” (w) Kariery i mobilność społeczno-zawodowa migrantów poakcesyjnych (red. E. Jaźwińska-Motylska). Warszawa: CMR Working Paper 65(123): 9-17.

Kędzierska, H. 2011. „Kariery zawodowe nauczycieli w labiryncie oświatowych przeobrażeń". Przeglq̨d Pedagogiczny 2: 78-87.

Labov, W., Waletzky, J. 2003. „Narrative analysis: oral versions of personal experience” (w) Sociolinguistics: The Essential Readings (red. C. Bratt Poulston, G. Tucker). Oxford: Blackwell: 74-104.

Lankiewicz, H. 2014. „From the concept of languaging to L2 pedagogy” (w) Languaging Experiences: Learning and Teaching Revisited (red. H. Lankiewicz, E. WąsikiewiczFirlej). Newcastle upon Tyne: Cambridge Scholars Publishing: 13-2.

Lichtenstein, B. M., Mendenhall, M. 2002. „Non-linearity and response-ability: Emergent order in 21st-century careers". Human Relations 5(1): 5-32.

Mach, B. 2003. Pokolenie historycznej nadziei i codziennego ryzyka. Społeczne losy osiemnastolatków z roku 1989. Warszawa: Instytut Studiów Politycznych PAN.

Mach, B. 2005.Transformacja systemu a trajektorie życiowe młodych pokoleń. Warszawa: Wydawnictwo IFiS PAN.

Magala, S. 2005. „Cyzelowanie zawodowych ram osobowości” (w) Konstruowanie jaźni i społeczeństwa. Europejskie warianty interakcjonizmu symbolicznego (red. E. Hałas, K. T. Konecki). Warszawa: WN SCHOLAR.

Matusik, S., Hill, C. 1998. „The utilization of contingent work, knowledge creation, and competitive advantage". Academy of Management Review 2: 680-97. 
Wykorzystanie narracji biograficznych w refleksji nad kształceniem nauczycieli...

Michalak, J. 2007. Uwarunkowania sukcesów zawodowych nauczycieli. Studium przypadków. Łódź: Wydawnictwo Uniwersytetu Łódzkiego.

Nizińska, A. 2008. Między nauczaniem a uczeniem się. Edukacyjne światy andragogówpraktyków. Wrocław: Wydawnictwo Naukowe Dolnośląskiej Szkoły Wyższej.

Pohoski, M. 1984. „Kariery szkolne i kariery społeczno-zawodowe a pochodzenie społeczne”. Kultura i Społeczeństwo 2: 155-171.

Polkingthorne, D. E. 1996. „Narrative knowing and the study of lives” (w) Aging and Biography: Explorations in Adult Development (red. J. Birren). New York: Springer: 77-99.

Reid, H. L. 2003. „Turning to narrative in the training of careers education, guidance, and advice workers: Could this be a way forward?". Career Research and Development, The NICE Journal 10: 3-9.

Reid, H. L. 2005. „Narrative and career guidance: Beyond small talk and towards useful dialogue for the 21st century". International Journal for Educational and Vocational Guidance 5: 124-136.

Reid, H. L. 2006. „Usefulness and truthfulness: Outlining the limitations and upholding the benefits of constructivist approaches for career counselling" (w) Career Counselling: Constructivist Approaches (red. M. McMahon, W. Patton). London, UK: Routledge: 30-41.

Ruohotie-Lyhty, M. 2013. „Struggling for a professional identity: Two newly qualified language teachers' identity narratives during the first years at work". Teaching and Teacher Education 30: 120-129.

Schein, E. 1978. Career Dynamics: Matching Individual and Organizational Needs. Reading, MA: Addison Wesley.

Schütze, F. 2005. „Cognitive figures of autobiographical extempore narration” (w) Biographical Research Methods Tom III (red. R. Miller). London: Sage Publications: 289-338.

Strauss, A. L. 1977. Mirrors and Masks. The Search for Identity. London: Robertson \& Co.

Squire, C. 2008. „Experience-centered and culturally-oriented approaches to narrative" (w) Doing Narrative Research (red. M. Andrews, C. Squire, M. Taboukou). Thousand Oaks: Sage: 42-63.

Stebleton, M. J. 2010. „Narrative-based career counselling perspectives in times of change: An analysis of strengths and limitations". Journal of Employment Counseling 47: 64-78.

Wąsikiewicz-Firlej, E. 2013. „Exploring the transition from academia to the workplace through career narratives of English philology graduates" (w) Kultur-Kommunikation-KreativtätReflexivität. Beiträge zum universitären Fremdsprachenunterricht (red. S. AdamczakKrysztofowicz, A. Szczepaniak-Kozak). Frankfurt am Mein: Peter Lang: 177-194.

Wąsikiewicz-Firlej, E. 2014. „Constructing the professional identity of EFL teachers through languaging: A narrative inquiry" (w) Languaging Experiences: Learning and Teaching Revisited (red. H. Lankiewicz, E. Wąsikiewicz-Firlej). Newcastle upon Tyne: Cambridge Scholars Publishing: 157-190.

Werbińska, D. 2009. „Tożsamość zawodowa nauczyciela języka angielskiego na starcie kariery zawodowej: badanie narracyjne" (w) Nauczyciel języków obcych dziś $i$ jutro (red. M. Pawlak, A. Mystkowska-Wiertelak, A. Pietrzykowska). Poznań-Kalisz: Wydział Pedagogiczno-Artystyczny UAM: 467-477. 